\title{
SINKHOLE SUSCEPTIBILITY MAPPING IN THE KUALA LUMPUR AND THE NEED FOR A BURIED KARST DATABASE
}

\author{
Vanessa J Banks \\ British Geological Survey, \\ Nicker Hill, Nottingham NG12 5GZ,UK,vbanks@bgs.ac.uk \\ Elanni Affandi \\ Department of Geology \\ Universiti Malaya, 50603, Kuala Lumpur, Malaysia.,elanniaffandi@gmail.com \\ Tham Fatt $\mathrm{Ng}$ \\ Department of Geology \\ Universiti Malaya, 50603, Kuala Lumpur, Malaysia, thamfatt@gmail.com
}

Christian Arnhardt

British Geological Survey,

Nicker Hill, Nottingham NG12 5GZ, UK, chrarn@bgs.ac.uk

\section{Zamri Ramli}

Ibu Pejabat Jabatan Mineral dan Geosains Malaysia,

Aras 8 dan 9, Menara PjH, No. 2, Jalan Tun Abdul Razak, Presint 2, 62100 Putrajaya, Malaysia., zamri@jmg.gov.my

\section{Ferdaus Ahmad}

Ibu Pejabat Jabatan Mineral dan Geosains Malaysia,

Aras 8 dan 9, Menara PjH, No. 2, Jalan Tun Abdul Razak, Presint 2, 62100 Putrajaya, Malaysia.

\section{Joy Pereira}

The National University of Malaysia

Institute for Environment and Development (LESTARI) 43600,Bangi, Malaysia, joy@ukm.edu.my

\section{Helen Reeves}

British Geological Survey,

Nicker Hill, Nottingham NG12 5GZ, UK, hjre@bgs.ac.uk

\begin{abstract}
One of the deliverables for the Newton Ungku Omar funded project: Disaster Resilient Cities: Forecasting local level climate extremes and physical hazards for Kuala Lumpur, awarded in 2016, was the development of a sinkhole susceptibility map for Kuala Lumpur. The purpose of the map was to contribute to the examination atmospheric and physical hazards in the context of climate extremes. At the commencement of the project there was no sinkhole database available to either inform or validate the mapping.
\end{abstract}

The geology of the Kuala Lumpur area comprises a flat, alluvial plain underlain by Cambrian Dinding Schist,
Ordovician Hawthornden Schist and metamorphosed Silurian Kuala Lumpur Limestone, capped to the west by the Kenny Hill Formation (Carboniferous to Permian quartzite and phyllite) and bounded on the east and west by Triassic granitic hills. The structural geology is complex, and the depth of weathered bedrock extends to 40 meters or more. Alluvial tin, derived from the granite ranges was trapped between karst pinnacles where they remained exposed. Consequently, the Silurian limestone is largely buried by a range of sediment types, including the Kenny Hill Formation, placer deposits and alluvium associated with the Klang Valley. 
In order to generate the sinkhole susceptibility map, a comprehensive literature review of karst landforms and reports of sinkholes was used to better characterize karst processes in the Kuala Lumpur region. Potential processes to affect karst susceptibility were translated into "rules" for GIS karst mapping (for example, geological boundaries between schists and limestones). The literature review highlighted the benefits of a buried karst feature database.

\section{Introduction}

The Kuala Lumpur Multi-Hazard Platform that was generated as the key output of the Newton-Ungku Omar Funded (NUOF) project on Disaster Resilience Cities: Forecasting Local Level Climate Extremes and Physical Hazards for Kuala Lumpur, comprises a decision support tool for the city council DBKL (Dewan Bandaraya Kuala Lumpur). It integrates air quality modelling with downscaled meteorological forecasting and geohazard information with respect to flooding, landslides and sinkholes. The project was delivered through a consortium comprising Malaysian and UK Partners from academia (University of Malaya, SEADPRI [South East Asian Disaster Prevention Research Initiative of the University Kebangsaan Malaysia], University of Cambridge, University College, London); government research institutions (Department of Mineral and Geoscience Malaysia, Met Malaysia, Department of the Environment Malaysia and British Geological Survey); consultant, (UKM Pakarunding, CERC (Cambridge Environmental Research Consultants), JBA, Geomapping Technology); small to medium enterprises (Cuesta and Core) and professional groups, such as the Geological Society of Malaysia and the Asian Network on Climate Science and Technology (ANCST), as well as the city council for Kuala Lumpur (DBKL). With respect to sinkholes the key output was a susceptibility map and some written guidance on how to use it.

The geology of the Kuala Lumpur area comprises a flat, alluvial plain underlain by a bedrock inlier of folded Cambrian, Ordovician and Silurian rocks, capped to the west by gently folded Permian to Triassic rocks and surrounded to the north, east and west by Triassic granitic hills (Table 1).

The structural setting is complex within Kuala Lumpur: to the north-west is the western structural belt of Ma- laysia and to the west is the Bentong-Raub Zone of subduction (Khoo and Tan, 1983; Metcalfe, 2013). North of Kuala Lumpur, the sub-vertical Klang Gates Quartz dyke was intruded along a 300 to $320 \mathrm{~m}$ trend, associated with the Kuala Lumpur Fault Zone, during the Cretaceous (Shuib, 2009).

Yeap (1993) described two phases of tin mineralization associated with the granite batholiths with hydrothermal fluid concentration in the upper parts of domal structures, locally breaching the overlying strata. The major component of the tin reserves of the Kuala Lumpur area occur as placer deposits, more specifically allochthonous kaska placers (Hutchison, 2009), derived from the granite ranges. The deposits are commonly cross bedded, and the mineral deposits are associated with favorable fluvial environments, e.g. point, braid and side bars (Hutchison, 2009). The Alluvial tin was trapped between karst pinnacles where they remained exposed. Consequently, the Silurian limestone is largely buried by a range of sediment types, including the Kenny Hill Formation, placer deposits and alluvium associated with the Klang Valley.

The depth of weathered bedrock extends to 40 meters or more especially in the low-lying areas (Suratman, 1988). Typically, the stiffness of tropical residual soils increases with depth. The exception is in the areas known as the slump zone, associated with dissolution of underlying limestone bedrock, where standard penetration test (SPT) N values can be reduced to zero (Singh, 1999; Tan, 2005). The slump zone can occur beneath a cover of stiff residual soil at depths of up to $100 \mathrm{~m}$, being a hidden hazard, as encountered at Petronas Towers (Persoski, 1996). It is most commonly encountered where the Kenny Hill Formation overlies the Kuala Lumpur Limestone and can range in thickness from 15 to $40 \mathrm{~m}$ (Suratman, 1988).

\section{Karst}

The karst is characterized by limestone hills (towers, pinnacles or mogote), which in Kuala Lumpur rise from alluvial valleys (Douglas, 2005). Twidale (2006) said that the pinnacles are the consequence of the sub-surface weathering achieved by deep phreatic waters retained in the regolith. The preservation of the pinnacles is attributed to the joint patterns in the bedrock, e.g. resistant compartments or cores during thrusting. Domal forms can be converted to towers as a result of failure above 


\begin{tabular}{|c|c|c|c|}
\hline Age & Formation & Member & Lithological description/ tectonic activity \\
\hline \multirow[t]{3}{*}{ Quaternary } & Anthropocene & & Mining related deposits \\
\hline & & & Residual soils \\
\hline & Simpang & & $\begin{array}{l}31-57 \mathrm{~m} \text { of Alluvium comprising unconsolidated river channel deposits } \\
\text { including sands and gravels overlain by orange mottled sandy clay, which in } \\
\text { turn is overlain by peat. These sediments contain placer tin deposits. The } \\
\text { sediments are commonly slumped into the pinnacles in underlying limestone } \\
\text { strata (Raj et al., 2009). }\end{array}$ \\
\hline Cretaceous & & & Uplift and onset of karstification \\
\hline Mesozoic & & $\begin{array}{l}\text { Granite } \\
\text { and } \\
\text { related } \\
\text { rocks }\end{array}$ & $\begin{array}{l}\text { Kuala Lumpur is surrounded by the granites of the Main Range Batholith } \\
\text { (Azman, 2000; Ghani, 2009). The Main Range comprises a number of large } \\
\text { granitic batholiths, west of the Bentong-Raub suture. The granite plutons } \\
\text { contain large metasedimentary enclaves (Ghani, 2009). }\end{array}$ \\
\hline $\begin{array}{l}\text { Early to Late } \\
\text { Triassic }\end{array}$ & & & $\begin{array}{l}\text { Collisional pan-Malay Peninsula orogeny (Metcalfe, 2013) } \\
\text { Compression, metamorphism and weathering }\end{array}$ \\
\hline $\begin{array}{l}\text { Carboniferous } \\
\text { to Permian }\end{array}$ & Kenny Hill & & $\begin{array}{l}1200 \text { to } 1500 \mathrm{~m} \text { of quartzite and phyllite derived from a sequence of } \\
\text { interbedded shallow water shale, mudstone and sandstone. Quartzose } \\
\text { sandstone is thickly bedded and fine to medium grained with a light yellowish } \\
\text { colour. Secondary iron oxide is derived from weathering and metamorphic } \\
\text { pyrite cubes, chlorite and mica in the sandstone. The dark coloured phyllite is } \\
\text { laminated and thin bedded, weathering to reddish brown or light grey. Slump } \\
\text { folds have been observed locally. Fossils including ammonite and crinoid } \\
\text { suggest a Permian age. To the north the sequence is deposited on the eroded } \\
\text { surface of the Kuala Lumpur Limestone Formation and forming an angular } \\
\text { unconformity (Lee, 2009) }\end{array}$ \\
\hline Devonian? & & & Compression, metamorphism and weathering \\
\hline Silurian & Kajang Schist & & $\begin{array}{l}\text { Dark grey to black carbonaceous quartz-muscovite schist with bands and } \\
\text { lenses of orange to buff quartz-muscovite schist and minor intercalations of } \\
\text { marble and phyllite (Hutchison, 2009b). }\end{array}$ \\
\hline \multirow[t]{2}{*}{$\begin{array}{l}\text { Silurian } \\
\text { Ordovician }\end{array}$} & $\begin{array}{l}\text { Kuala Lumpur } \\
\text { Limestone }\end{array}$ & & $\begin{array}{l}\text { Weakly metamorphosed limestone and marble: finely crystalline grey to } \\
\text { cream, thickly bedded with variable degrees of dolomitization. Corals of } \\
\text { probable mid-Silurian age have been found (Lee, 2009). }\end{array}$ \\
\hline & $\begin{array}{l}\text { Hawthornden } \\
\text { Schist }\end{array}$ & & $\begin{array}{l}\text { Up to } 910 \mathrm{~m} \text { of carbonaceous schist and phyllite The upper part is equivalent } \\
\text { to the Kuala Lumpur Limestone Formation. Orthoceratids and a gastropod } \\
\text { have been found (Hutchison, 2009b). }\end{array}$ \\
\hline Cambrian & Dinding Schist & & $\begin{array}{l}\text { Up to } 3400 \mathrm{~m} \text { of quartz-mica schist, metaquartzite and subsidiary actinolite, } \\
\text { diopside and epidote schist and schistose conglomerate. The upper part } \\
\text { comprises meta-rhyolite. No fossils have been reported (Hutchison, 2009b). }\end{array}$ \\
\hline
\end{tabular}

Table 1. Summary of the geological history of Kuala Lumpur.

basal notches. Much of the karst of the Kuala Lumpur region is buried karst, which is difficult to characterize, but it can generally be classified as being of class kIV or kV (Waltham and Fookes, 2003), or in terms of local classifications, e.g. Yeap (1997). The buried karst also includes dolines, cavities, overhangs, mass rock head and channels. The pinnacled rock head can exhibit changes in depth up to $100 \mathrm{~m}$ over very short distances and between the pinnacles buried sinkholes are present. The Limestone hills exhibit a succession of notches, as a result of solutionally enlarged conduit systems, possibly indicative of Pleistocene interglacial high sea levels at least $70 \mathrm{~m}$ above current sea level. It has been suggested that they are formed by swamp waters and subsoil solu- tion may be associated with the formation of cliff foot caves. Quaternary fluctuations in sea level were up to $120 \mathrm{~m}$ below sea level.

The limestone hill (Figure 1) of Batu Caves outcrops as a $200 \mathrm{~m}$ hill that is the only natural exposure of the limestone in the Kuala Lumpur area. The phreatic nature of the caves suggest that they formed under different hydrological conditions. It has been suggested (Crowther, 1983) that the limestone outcrops formerly transmitted large volumes of allogenic runoff from the adjacent granites in the Main Range and that the current drainage is a remnant of the former. In their assessment of the structural guidance of karst processes Zabidi and 
de Freitas $(2006,2011)$ differentiate between subsurface karst developed at rock head and the more pervasive development of permeability within the limestone. Additionally, there is some evidence of hypogene karst, likely associated with late stage iron mineralization (Banks et al., 2019).

\section{Geohazards}

There is a legacy of ground related collapses in the Kuala Lumpur region due to instability in the former mining areas, e.g. subsidence in mining related slimes and tailings with either land sliding of the mine slope or subsidence caused by consolidation settlement of the underlying slime (Tan and Komoo, 1990); dewatering of groundwater near mining area (Suratman, 1988), or slope failure due to excess pore pressures resulting from rapid draining of former reservoirs in abandoned mine areas (Tan, 2006). Excessive differential settlement has been reported in areas underlain by municipal waste (Tan and Komoo, 1990). Slope failures have also been reported in residual soils and schists, as well as the Kenny Hill Formation metasediments (Tan and Komoo, 1990). Collapse of soil in the slump zone above limestone bedrock has been encountered during investigations for multistory buildings (Tan and Komoo, 1990). In areas underlain by limestone the problems of differential settlement or subsidence is due to variation in depth to rock head in pinnacle karst, and subsidence related to dissolution in karst limestone, have been reported.

\section{Sinkholes}

Dolines associated with the Batu Caves are generally circular to elongated, 7 to $45 \mathrm{~m}$ across. They commonly appear to be aligned with dominant structural trends (Figures 2 and 3). In the Kuala Lumpur region sinkholes have been linked to a number of triggering processes and can generally be classified as suffusion and dropout dolines (Waltham et al., 2010) in the alluvial and weathered sediments. It is understood that most are triggered by anthropogenic activities, such as tunneling (Tan, 2017); loss of fines by groundwater seepage and piping; vibration; changes to groundwater levels; excavation of roofs' cavities. Tan et al. (2005) suggest that they are particularly common in areas where the cover thickness is less than $3.5 \mathrm{~m}$ above the limestone and particularly when triggered by groundwater withdrawal.

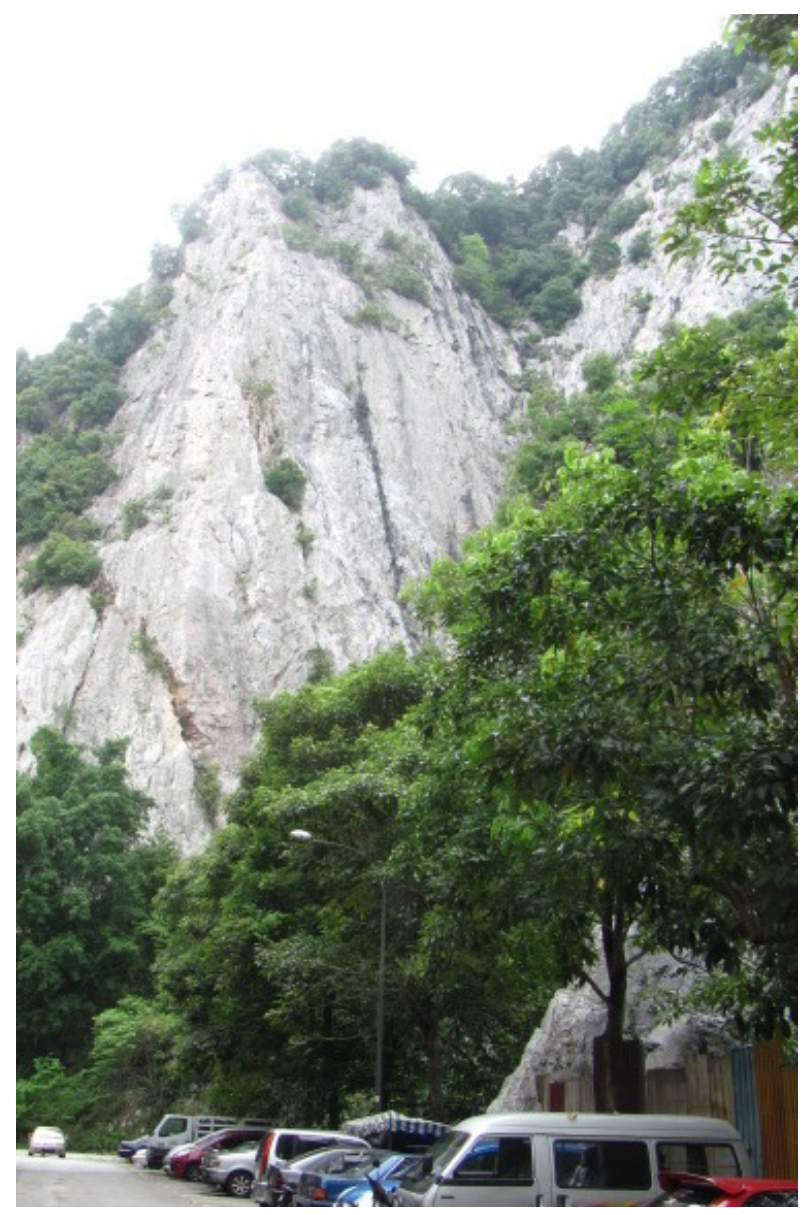

Figure 1. Sub vertical bedding in marbleised limestone of the Kuala Lumpur Formation.

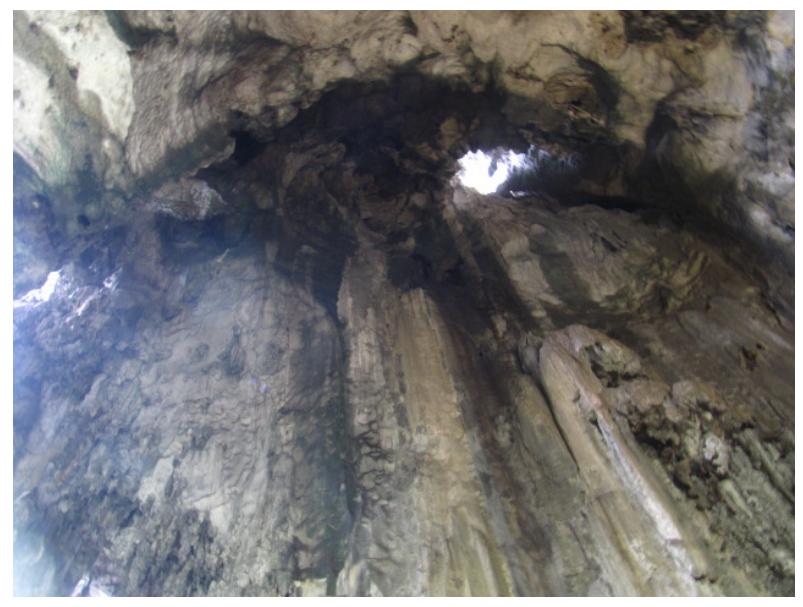

Figure 2. Limestone hills rise to $200 \mathrm{~m}$ above the alluvial valley floors. 


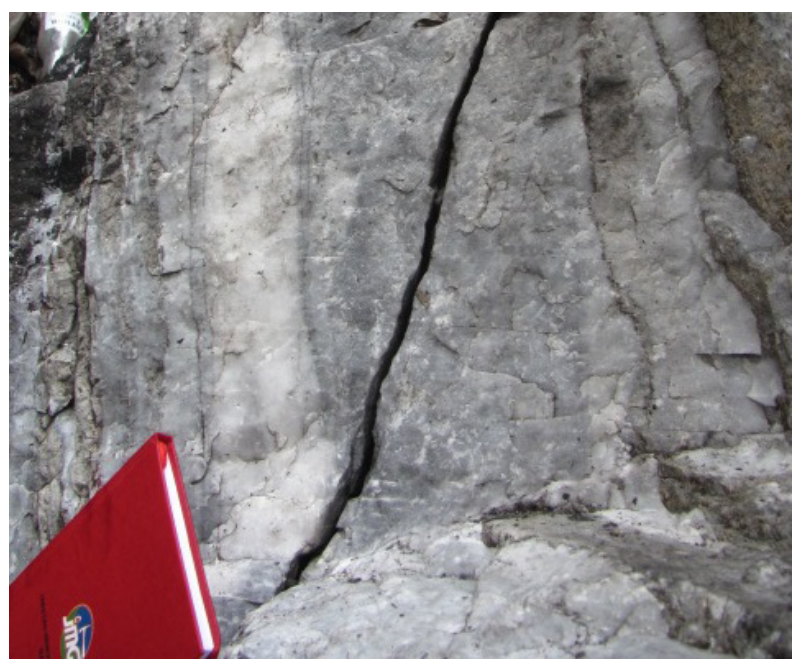

Figure 3. Structural alignment of shaft in Batu Cave, Kuala Lumpur.

\section{Sinkhole susceptibility}

A sinkhole susceptibility map developed by Rosdi et al. (2017) using GIS and analytical hierarchical process (AHP) appears to capture the principal conditioning factors: lithology, soil type, land use, water level decline and proximity to groundwater and applies a normalized weighting of each of the criteria. The resulting susceptibility map was presented with five classes of susceptibility (very low to very high). Analysis of 33 sinkholes from a database maintained by the Department of Mineral and Geoscience Malaysia (JMG) found that $24 \%$ of the sinkholes are within the moderate and low susceptibility classes.

In the absence of a fully attributed database of sinkholes the approach that was adopted by the NUOF project was to use the literature and stakeholder engagement to consider the processes potentially associated with karst and sinkhole triggering in the Kuala Lumpur region to generate a set of criteria for susceptibility mapping. While a number of potentially influencing factors were identified from the literature and engagement with stakeholders, e.g. Table 2, the evidence for these factors was found to be very limited, because of the rareness of exposure of the limestone in the Kuala Lumpur region.

Ultimately, in the absence of a validated evidence base, the criteria for developing the susceptibility map (Figure 4) were limited to areas underlain by karst (buried karst) and the potential slump zone. It is anticipated that this
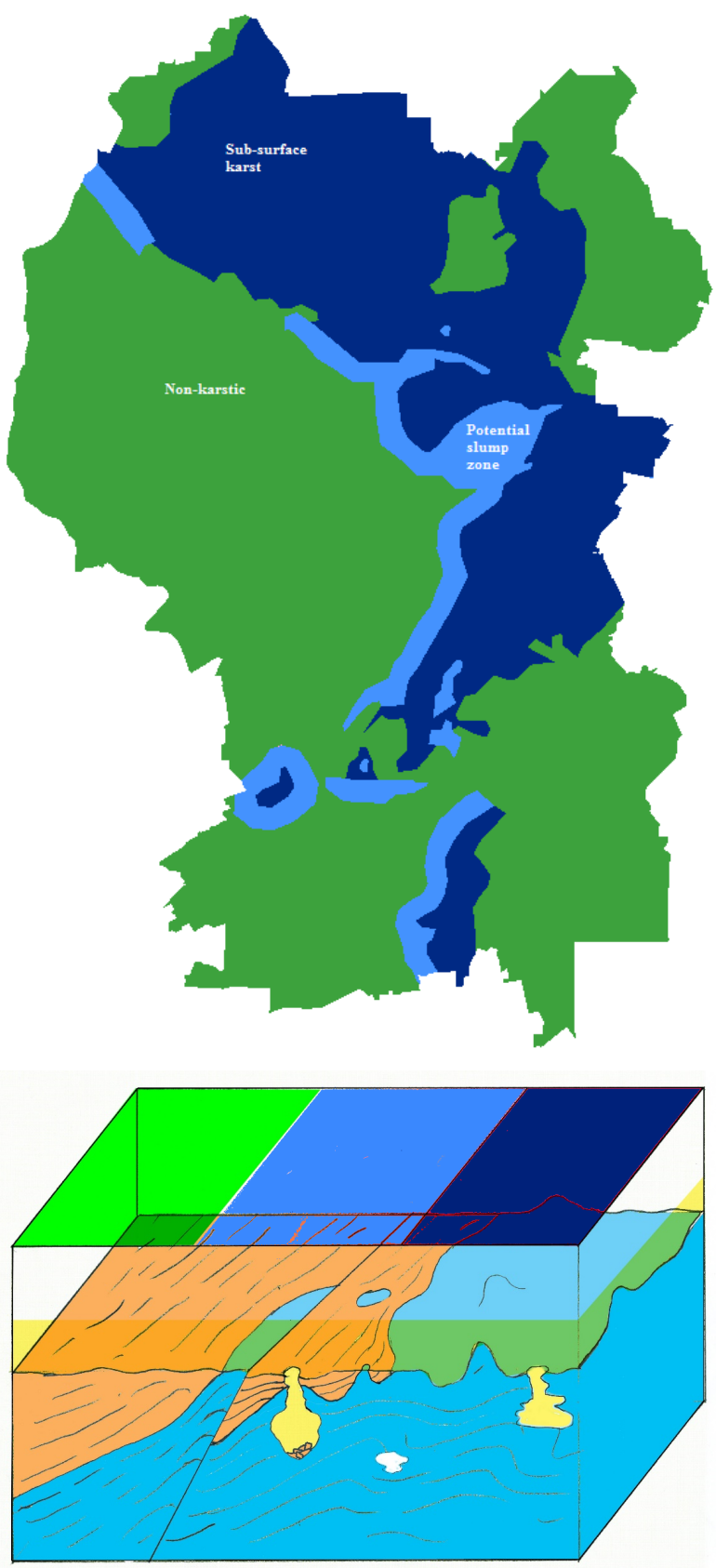

Figure 4. (a) Sinkhole susceptibility map for Kuala Lumpur with (b) conceptual model to show the slump zone corresponding to thrusting of the Kenny Hill Formation and the Kuala Lumpur Limestone Formation.

map will be most useful as a reminder to consider the potential for sinkhole formation at the planning stage of the project. The map is also accompanied by a conceptual model that shows the potential for juxtaposition of 


\begin{tabular}{|c|c|}
\hline Item & Description \\
\hline 1 & $\begin{array}{l}\text { Lithological variation: evident in the weakly metamorphosed marble; potential for striped } \\
\text { karst in dolomitized zones, and formation contacts, e.g. granite to limestone or Kenny Hill } \\
\text { Formation to limestone }\end{array}$ \\
\hline 2 & Stylolites ruled, out as a factor, as most appear to be tight \\
\hline 3 & Unsaturated zone karst features focusing on joints and sub-vertical bedding \\
\hline 4 & $\begin{array}{l}\text { Palaeokarst reported in the literature and associated with the development of the slump } \\
\text { zone }\end{array}$ \\
\hline 5 & Hypogene karst associated with granite batholiths and mineralization \\
\hline 6 & Impacts of Neotectonics and Quaternary sea level change \\
\hline 7 & Lithological focusing of flow \\
\hline 8 & $\begin{array}{l}\text { Lithological juxtaposition, e.g. dissolution of pyrite in Kenny Hill Formation leading to } \\
\text { limestone dissolution, particularly in the slump zone }\end{array}$ \\
\hline 9 & $\begin{array}{l}\text { In marbleised limestone, primary porosity is occluded by diagenesis and tectonic inception } \\
\text { is the most efficient way for karst porosity to develop Faulkner (2006), such that the stress } \\
\text { history and tectonic inception due to uplift may influence karst evolution }\end{array}$ \\
\hline 10 & $\begin{array}{l}\text { Lineaments, particularly faults generally comprise a number of zones that will guide karst } \\
\text { processes in different ways, e.g. fault core, breccia and cataclastites (Fossen, 2010) }\end{array}$ \\
\hline 11 & Discontinuity intersections \\
\hline 12 & Slope angles focusing flow \\
\hline 13 & Vegetation with its potential to contribute carbon dioxide to infiltrating meteoric water \\
\hline 14 & Groundwater conditions \\
\hline 15 & $\begin{array}{l}\text { Folding causing anticlinal opening of joints facilitating unsaturated zone karstification, } \\
\text { leading to deep shafts }\end{array}$ \\
\hline 16 & Anthropogenic activities, such as mining \\
\hline
\end{tabular}

Table 2. Potential factors influencing sinkhole susceptibility.

schists (pyrite bearing) and marble in areas of multiple thrusts with the potential for striped karst resulting from the dissolution associated with the generation of sulphuric acid by the oxidation of pyrite.
Future refinement of the susceptibility map Our current understanding of sinkhole triggering processes suggests that improvements to the susceptibility map could be brought through: (i) better understanding of groundwater conditions; (ii) higher resolution structural mapping; (iii) mapping and interpretation of sub-surface 
karst features of the existing data base, and (iv) updates of the sinkhole database. Geohazard databases prove to be useful when they are subject to ongoing maintenance and capture geometrical information (width, depth, and orientation), geology, date, groundwater conditions, triggering and inception processes, as well as location and impact. The recording of impact data provides information that may influence future decision making. Intensive development of the Kuala Lumpur sub-surface, e.g. SMART tunnels and metro systems has generated borehole data that lends itself to analysis for data on sub-surface karst, structures and groundwater and it is anticipated that this research will be undertaken within the context of $\mathrm{PhD}$ research contributing to the NUOF project.

\section{Acknowledgements}

This project was administered by Innovate UK and the Malaysian Industry-Government Group for High Technology (MIGHT). It is led by Professor Joy Pereira (SEADPRI, University Kebangsaan Malaysia) and Professor Lord Julian Hunt (University of Cambridge). The paper is published with the permission of the Executive Director of the British Geological Survey, UKRI.

\section{References}

Azman, AG. 2000. The Western Belt granite of Peninsular Malaysia: some emergent problems on granite classification and its implication. Geosciences Journal 4 4: 283 - 293.

Banks, VJ., Affandi E, Ng TF, Muhammad R, Lim T. 2019. Report on a field visit to Batu Caves, Kuala Lumpur, Malaysia. Cave and Karst Science 46 No. 3: $135-137$.

Crowther J. 1983. Hydrology of autogenic percolation systems in some tropical karst outcrops, West Malaysia. Journal of Hydrology 60; 227-242.

Douglas I. 2005. The urban geomorphology of Kuala Lumpur. In: Gupta A. Editor. 2005. The Physical Geography of Southeast Asia. Oxford University Press.

Faulkner T. 2006. Tectonic inception in Caledonide marbles. Acta Carsologica 35 (1): 7-21.
Fossen, H. 2010. Structural Geology. Cambridge University Press.

Ghani AA. 2009. Plutonism. In Hutchison CS. and Tan DNK. (Eds). 2009. Geology of Peninsular Malaysia. University of Malaya and the Geological Society of Malaysia. p. 211 - 231.

Hutchison CS. 2009. Mineral Deposits. In Hutchison, CS. and Tan DNK. (Eds). 2009. Geology of Peninsular Malaysia. University of Malaya and the Geological Society of Malaysia. p. 331 - 363.

Hutchison, C.S. 2009b. Bentong-Raub Suture. In Hutchison CS. and Tan DNK. (Eds). 2009. Geology of Peninsular Malaysia. University of Malaya and the Geological Society of Malaysia. p. $43-53$.

Khoo TT, Tan BK. 1983. Geological evolution of peninsular Malaysia Workshop on stratigraphic correlation of Thailand and Malaysia. 8-10 September 1983. 253-290.

Lee CP. 2009. Palaeozoic Stratigraphy. In Hutchison, CS, Tan DNK. (Eds). 2009. Geology of Peninsular Malaysia. University of Malaya and the Geological Society of Malaysia. p. $55-86$.

Metcalfe I. 2013. Tectonic evolution of the Malay Peninsula. Journal of Asian Earth Sciences. 76 195-213.

Peroski, H. 1996. The Petronas Twin Towers. American Scientist 84 (4): (July-August 1996) 322-326.

Raj JK, Tan DNK and Wan Hasiah Abdullah. 2009. Cenozoic Stratigraphy. In Hutchison, CS. and Tan, DNK. (Eds). 2009. Geology of Peninsular Malaysia. University of Malaya and the Geological Society of Malaysia. p. 133 - 173.

Rosdi MAHM, Othman AN, Zubir MAM, Latif ZA, Yusoff ZM. 2017. Sinkhole susceptibility hazard zones using GIS and analytical hierarchical process (AHP): a case study of Kuala Lumpur and Ampang Jaya. The International Archives of the Photogrammetry, Remote Sensing and Spatial Information Sciences XLII-4/W5: 145-151.

Shuib MK. 2009. Structures and Deformation. In Hutchison CS, Tan DNK. (Eds). 2009. Geology of Peninsular Malaysia. University of Malaya and the Geological Society of Malaysia. p. 271-308. 
Singh M. 1999. Limestone Profile along LRT System Two for Kuala Lumpur. Paper presented at the IEM-GSM Forum "KARST: Geology \& Engineering", The Institution of Engineers, Petaling Jaya, Malaysia.

Suratman S. 1988. Engineering geological mapping of Wilayah Persekutuan and surrounding areas: Volume1: Ampang- Ulu Klang and Damansara zones. Kuala Lumpur: Geological Survey of Malaysia.

Tan BK. 2017. Engineering geology in Malaysia some case studies. Bulletin of the Geological Society of Malaysia 64 (1): 65-79.

Tan BK. 2006. Urban geology of Kuala Lumpur and Ipoh, Malaysia. IAEG 2006. Paper 24. 7 p.

Tan BK. and Komoo I. 1990. Urban Geology: Case study of Kuala Lumpur, Malaysia. Engineering Geology 28, 71-94.

Tan BK. and Siti FE Bt M. 2005. Physico-chemical properties of residual soils of the Kenny Hill Formation in the Shah Alam area, Selangor. Geological Society of Malaysia Bulletin 51 June 2005: 13-17.

Tan SM. 2005. Karstic Features of Kuala Lumpur Limestone. Jurutera Bulletin 6: 64.

Twidale CR. 2006. Origin and development of Karstinselberge, with particular reference to some South East Asian evidence. Geological Society of Malaysia Bulletin 49: 145 - 155.

Waltham AC, Fookes P. 2003. The engineering classification of karst ground conditions. Quarterly Journal of Engineering Geology and Hydrogeology 36: 101-118.

Waltham AC, Bell FG, Culshaw MG. 2010. Sinkholes and Subsidence: Karst and cavernous rocks in engineering and their construction. Springer $382 \mathrm{p}$.

Yeap EB. 1997. The types and the origin of carbonate karsts in Malaysia and their significance. Warta Geologi 23 (3): May-Jun 1997

Yeap EB. 1993. Tin and gold mineralizations in Peninsular Malaysia and their relationships to the tectonic development. Journal of Southeast Asian Geological Sciences 8 1-4: 329-348.

Zabidi H, de Freitas MF. 2006. Structural studies for the prediction of karst in the Kuala Lumpur Limestone. International Association of Engineering Geology Conference Nottingham, Paper 264 7p.

Zabidi H, de Freitas MF. 2011. Preferred direction of karst in the Kuala Lumpur Limestone Formation: a SMART tunnel case study. Asean Engineering Journal Part C. 1 (3): 152-161. 